\title{
The Effect of Red Pitaya Peel (Hylocereus polyrhizus Extract) on Malondialdehida Levels and Histopathology Profile in Diazinon Induced Rat (Rattus norvegicus)
}

\author{
Chanif Mahdi $^{*}$, Viski Fitri Hendrawan ${ }^{2}$, Khoirus Viestaria ${ }^{2}$ \\ ${ }^{1}$ Faculty of Sciences, Universitas Brawijaya, Malang, Indonesia \\ ${ }^{2}$ Faculty of Veteriner, Universitas Brawijaya, Malang, Indonesia
}

\begin{abstract}
Diazinon, an organophosphate insecticide is widely used in agricultural sectors. The metabolic products of this organophosphate compound can increase Reactive Oxygen Species (ROS) in the body. It causes complications to the various organs, one of which is gastric. Red pitaya peel extract (Hylocereus polyrhizus) has high antioxidant activity in lowering ROS, in cases of diazinon poisoning. This study aims to determine the effectiveness of redpitaya peel extract in reducing the levels of Malondialdehyde (MDA) and repairing histopathological damage of rats induced by diazinon. This study used 20 tails of male white Wistar rats (Rattus norvegicus) from 8-12 weeks of age with the average weight of 150 grams . The subject was divided into 5 groups, which were negative control (-), positive control (+), treatment $1(\mathrm{P} 1)$, treatment $2(\mathrm{P} 2)$, and treatment $3(\mathrm{P} 3)$. A dose of $40 \mathrm{mg} / \mathrm{kg}$ BW of Diazinon was given orally every day through feeding tube (sonde) for 5 consecutive days. Red pitaya peel extract was given to test groups with a dose of $150 \mathrm{mg} / 150 \mathrm{~g} \mathrm{BW}$, $200 \mathrm{mg} / 150 \mathrm{~g}$ BW and $250 \mathrm{mg} / 150 \mathrm{~g}$ BW, for 14 days. MDA levels were measured using the Thiobarbituric acid (TBA) test. Gastric histopathology features were stained with Hematoxylin-Eosin (HE) after 14 days. The MDA levels were analyzed quantitatively by ANOVA using SPSS version 22 for Windows and continued with honestly significant difference (HSD) test $(\alpha=5 \%)$ and gastric histopathology were analyzed descriptively. The results showed that the extract of red pitaya peel with dose of $150 \mathrm{mg} / 150 \mathrm{~g} \mathrm{BW}$ significantly $(p<0.01)$ reduces MDA level in gastric dan improves the histopathology of the gastric. Red pitaya peel extract at a dose of $150 \mathrm{mg} / 150 \mathrm{~g}$ BW was able to significantly decrease MDA levels and improve the histopathology feature of the gastric in white rats induced by diazinon. So this can be summarised that giving red pitaya extract in rats have a very significant effect on the level of malondialdehyde production and it could repair rats stomach tissue that induced by diazinon.
\end{abstract}

Keywords: diazinon, histopathology, MDA, red pitaya peel

\section{INTRODUCTION}

Pesticides become a major threat to the Indonesian society today, where is widely used especially in the agricultural sector as a plant pest control such as aphids, grasshoppers, ants, flies, caterpillars and other insects (Mishra and $\mathrm{Ku}$ -

Submitted: April 30, 2019

Revised: June 24, 2019

Accepted: June 25, 2019

*Corresponding author: chanifmahdi@gmail.com 
mari, 2015). In 2010 the World Health Organization (WHO) stated that about 5000-10.000 people are poisoned by pesticides and will increase especially in developing countries. In 2013, it has been reported that $88 \%$ of Cambodian farmers are positively acute poisoned by pesticides and in Indonesia, it has been reported about 12.000 cases of death from pesticide poisoning each year (Zulmi, 2016).

Based on the target organism, pesticides are grouped into herbicides, fungicides, and insecticides. An insecticide is used to eradicate plant pests. It made by organophosphates or non-organophosphates. One of the most widely used organophosphates is diazinon. Diazinon is frequently used to control insects in foliage, vegetables, fruits, and other agricultural crops. A continuous exposed of diazinon will leave residues in the plant, either on leaves, fruit, stems or soil. A human can be consuming these plants (Budiyono, 2012). Organophosphorus poisoning can lead to accumulation of free radicals and oxidative stress in membrane cell. Oxidative stress will induce lipid peroxidation, a polyunsaturated fatty acid oxidation process in cell membranes that produce radical peroxides, hydroperoxides, and aldehyde products, eg Malondialdehyde (MDA) (Palupi, et al., 2012).

According to Lesmana, et al., (2013), one of the gastrointestinal organs that first orally induced by diazinon is gastric. Diazinon can increase the oxidative stress that caused the cell damage in gastric tissue, so it is necessary to observe histopathology of gastric organs. Diazinon has a harmful effect when consumed. It may cause epithelial damage to the mucosal tunica, rupture of submucosal tunica even occasionally to muscular, hyperemic tunica blood vessels, and visible infiltration of inflammatory cells in submucous and muscular tunics which can be observed by gastric histopathology examination (Kumari and Mirshra, 2015).

Currently the treatment in cases of poisoning pesticides rely solely on chemical drugs that also have side effects on human health. This makes the community to switch to traditional medicine that is considered as safe and not harmful to the body, be- cause it comes from nature (Sugiyanta, et al., 2013). Another natural ingredient that has high antioxidant activity is red pitaya peel because it has high antioxidant activity, so it is good for health when consumed. According to some studies, the highest antioxidant activity is found on the peel (Putri, et al., 2015). Red pitaya peel is currently not widely used, people tend to consume fruit and the peel is removed as agricultural waste. In the pharmacological red pitaya peel can be used as a promising herbal medicine as an antioxidant in reducing free radicals in the body (Putri, et al., 2015).

This study was conducted to determine the effect of red pitaya peel extract in diazinon induced gastric damage of white rats on MDA levels and gastric histopathology.

\section{MATERIALS AND METHODS}

\section{Equipments and materials}

The equipment used in this research include cages, drinking bottles, feeding places, disposable syringe $1 \mathrm{~mL}$ and $5 \mathrm{~mL}$, digital scales, scalpels, blades, scissors, object glasses, scissors, tweezers, blenders, measuring cups, vortex, Eppendorf, micropipette, water bath, light microscope, spectrophotometer, glass cover, refrigerator, incubator, plastic the clip, and microtome.

The materials used in this research were male white Wistar rats, the feed and drink for white rat, Red pitaya peel extract, diazinon $600 \mathrm{EC}, \mathrm{TCA}, \mathrm{HCl} 1 \%$, Na- Thiol, $\mathrm{NaCl} 0.9 \%$, aquadest, $96 \%$ ethanol, ethanol absolute, 70\% ethanol, $80 \%, 90 \%$, 95\%, xylol, paraffin, Hematoxylin eosin, filter paper, and formalin $10 \%$.

\section{Experimental Animal Preparation}

The experimental animals used were 8-12 weeks male white rats, Wistar strains with an average body weight of $150 \mathrm{~g}$. Acclimatization for 7 days with feed ad-libitum. This research has received ethical clearence from Research Commission of Universitas Brawijaya, Number: 765-KEP-UB. 


\section{Red Pitaya Peel Extracts Preparation}

The red pitaya peel extract was made by having the 1000 grams of smooth red pitaya peel macerated for 24 hours using 96\% ethanol solvent and $1 \% \mathrm{HCl}$ with a ratio of 9: 1 volume of $1000 \mathrm{~mL}$ followed by filtration. The filtered mashrates are then collected and stored at room temperature protected from sunlight. The yield of all $96 \%$ ethanol acetate was evaporated with a rotary evaporator at $40{ }^{\circ} \mathrm{C}$ until a thick ethanolic extract was obtained (Putri, et al., 2015).

\section{Induction of Diazinon in the White Rat}

The induced diazinon in white rats is a 600 EC. The liquid dose of $40 \mathrm{mg} / \mathrm{kg} \mathrm{BW}$ administered per oral every once daily for 5 days.

\section{Red Pitaya Peel Extract Therapy}

Administration of therapy using red pitaya peel extract used a dose at treatment 1 (P1) was $150 \mathrm{mg} / 150 \mathrm{~g} \mathrm{BB}$, treatment 2 (P2) was $200 \mathrm{mg} / 150 \mathrm{~g} \mathrm{BB}$, and treatment 3 (P3) was $250 \mathrm{mg} / 150 \mathrm{~g} \mathrm{BB}$. Treatment is given to white rats previously induced by diazinon. Treatment is given orally via sonde every day for 14 days.

\section{Measuring Gastric MDA Levels}

The gastric of 0.225 grams was obtained from experimental animal surgery. Gastric organs are cut into small pieces, given a little quartz sand and crushed in a cold mortar. The crushed sample was added $1 \mathrm{~mL} \mathrm{NaCl} 0.9 \%$. Homogenate is transferred into microtube and centrifuged at $8000 \mathrm{rpm}$ for 20 minutes. After centrifugation, the supernatant is removed as much as $100 \mu \mathrm{L}$, transferred into a new microtube. Aquadest is added as much as $500 \mu \mathrm{L}$ into the microtube and homogenized with a vortex. TCA solution was added as much as 100 $\mu \mathrm{L}$ into microtube and homogenized again using vortex. The $\mathrm{HCl}$ in solution is added to the microtube by $250 \mu \mathrm{L}$ and homogenized with the vortex.

Na-Thiol solution added as much as $100 \mu \mathrm{L}$ into microtube and re-homogenized with vortex and microtube centrifuged at $500 \mathrm{rpm}$ for 15 minutes. The supernatant formed is taken from the microtube and inserted into the new microtube. Incubated in water-bath at $100{ }^{\circ} \mathrm{C}$ for 30 minutes, after which the microtube is opened and left in room temperature. The absorbance measurements with the TBA test at $\lambda \max (530 \mathrm{~mm}$ ) using the UV-1601 spectrophotometer (Shimadzu UV-visible spectrophotometer) were plotted on the standard curve that has been made for the calculation of the sample concentration.

\section{Histopathology Preparations}

After euthanization and surgery, the gastric organs were fixated into $10 \%$ formalin solution up to a maximum of 2 days. Furthermore, this organ was undergone processes including dehydration, clearing, immersion in paraffin, embedding, sectioning, attachment of an object digestion, and HE staining. The histopathologic features of the gastric were analyzed descriptively by observing damage of the gastric mucosal tunica in particular gastric epithelial (erosion) and infiltration of inflammatory cells which were seen using a 100x and 400x magnification light microscope.

\section{Data analysis}

The parameters in this study were MDA levels and the histopathological damage appearance of gastric rat. MDA levels were measured using the TBA test. Data of MDA level was analyzed quantitatively using ANOVA test by SPSS version 22 for windows and continued with Posthoc Honestly Significant Difference (HSD) test $(\alpha=5 \%)$. Gastric histopathology was analyzed descriptively by observing the damage through light microscopy of $100 x$ and 400x magnification.

\section{RESULTS AND DISCUSSION}

\section{MDA Level Measurement}

MDA is an aldehyde compound which is the final product of lipid peroxidation, due to oxidative stress as a result of free radicals exposure 
in the body. Indirectly increased levels of MDA can be used as biomarker oxidative stress occurs, whereas the decreased MDA levels may indicate organ improvement (Lianiwati, 2011). MDA levels were obtained from the TBA test and then performed statistical analysis using ANOVA. The ANOVA analysis showed highly significant differences in MDA levels between treatment groups ( $p$ $<0.01)$ and HSD test $(\alpha=5 \%)$ shown in the Table 1 .

Table 1. Measurement Result of Malondialdehyde Level (MDA) of Each Treatment Group

\section{Groups Average of MDA Level (ng/100mg)}

\begin{tabular}{ll}
\hline Negative Control (-) & $0.164 \pm 0.035^{\mathrm{a}}$ \\
Positive Control $(+)$ & $0.445 \pm 0.08^{\mathrm{b}}$ \\
Treatment $1(\mathrm{P} 1)$ & $0.233 \pm 0.05^{\mathrm{a}}$ \\
Treatment $2(\mathrm{P} 2)$ & $0.219 \pm 0.036^{\mathrm{a}}$ \\
Treatment $3(\mathrm{P} 3)$ & $0.209 \pm 0.104^{\mathrm{a}}$
\end{tabular}

Description: Different notation $(\mathrm{a}, \mathrm{b})$ indicates result of statistical analysis (Tukey HSD test). There's a significant difference between treatment groups $(p<0.01)$.

The table above (Table 1) shows that extract of red pitaya peel decrease MDA levels previously increased due to exposure of diazinon, that induced per-oral in groups $\mathrm{P} 1, \mathrm{P} 2$, and $\mathrm{P} 3$. The decrease of MDA level in the gastric organ is caused by the administration of red pitaya peel extract therapy containing an antioxidant compound, antosianin which can ward off free radical in the body. According to Lianiwati (2011), Antosianin works by donating hydrogen atoms to free radicals and causing them to be stable. The balance between oxidants and antioxidants causes the level of oxidative stress to decrease, thereby decreasing MDA levels in the tissues

\section{Observation Histopathology of Gastric}

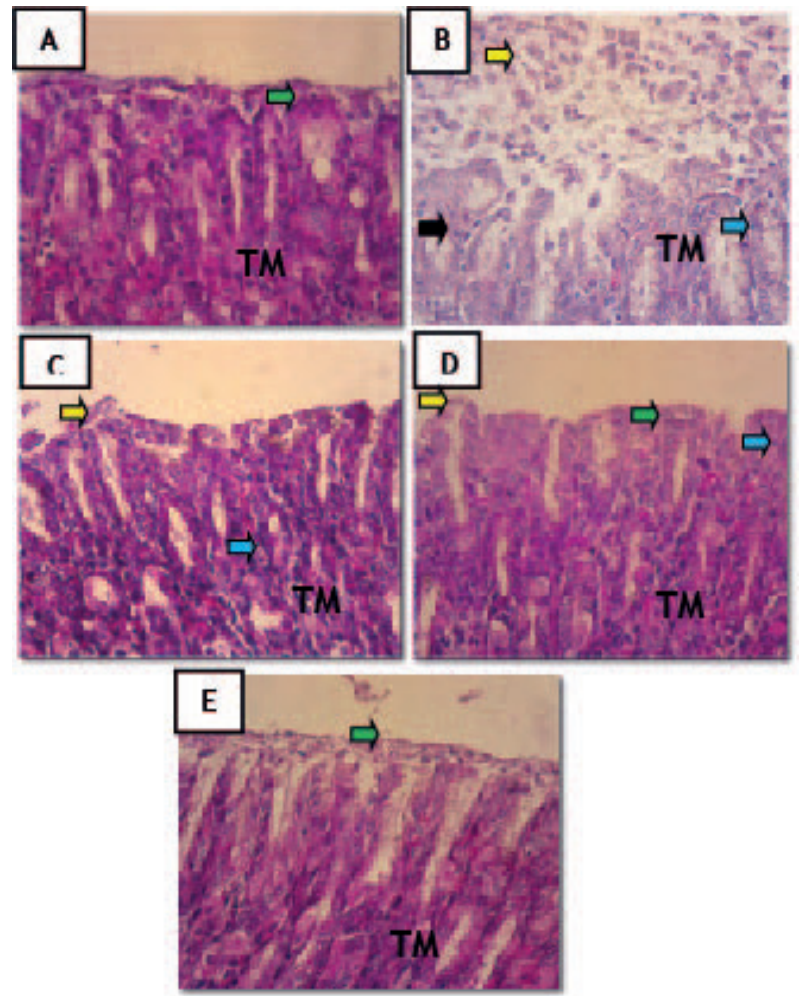

Figure 1. The gastric histopathology of white rats group $\mathrm{A}(\mathrm{K}-), \mathrm{B}(\mathrm{K}+), \mathrm{C}(\mathrm{P} 1), \mathrm{D}(\mathrm{P} 2)$ and $\mathrm{E}(\mathrm{P} 3)$ with $\mathrm{HE}$ staining and 400x magnification.

Description: ( $)$ shows epithelial cell rupture due to epithelial erosion of the tunica mucosa, $(\widehat{\top})$ indicates infiltration of inflammatory cell, ( 1 ) shows the nucleus of parietal cells experiencing pythonic, $(\widehat{U})$ indicates regeneration of epithelial cell, there appears to be an improvement on surfaces of the tunica mucosa. TM = tunica mucosa.

The histologic features of the gastric of the $\mathrm{K}(-)$ group, the white rat animal which is not given any treatment indicate normal gastric histopathology, apparently tunica mucosa of gastric still intact. The histopathologic features of the $\mathrm{K}(+)$ group appear epithelial erosion of the tunica mucosa, parietal cell phenolic necrosis, and infiltration of inflammatory cells. This damage occurs because in the $\mathrm{K}$ group $(+)$ were orally induced diazinon at a dose of $40 \mathrm{mg} / \mathrm{kg}$. Diazinon directly irritates epithelial cells 
in the tunica mucosa by lowering the barrier of the gastric mucosa. It also forms the free radicals that damage the cell membrane by increasing superoxide anions and the production of hydroxyl radicals and lipid peroxidation, the final result is an increase in MDA levels in the gastric (Lianiwati, 2011). The resulting oxidative stress can also increase mitochondrial permeability and mitochondrial depolarization causing cell death (Sugiyanta, et al., 2013). Before the cell is necrosis or cell death, the nucleus cell will become python. In the histopathology picture, python cell nucleus are characterized by physics characterized by darker-looking cell nucleus compared to normal parietal cell nucleus. This is because the chromosomes inside the pythonic nucleus undergo homogeneity, so the cell nuclei absorb many dyes and make the cell nucleus dark. whereas the cells undergoing necrosis it will appear that the nucleus cell is destroyed and parts of the cell are not clearly visible (Yulihastuti, et al., 2016). The use of chemical compounds can cause epithelial erosion, which is the rupture of epithelial cells on the surface of the tunica mucosa with the inside of the mucosa still intact (Romdhoni, 2015).

The histopathology features of the gastric in the treatment groups P1, P2, and P3 showed an improvement in histopathology feature compared with $\mathrm{K}(+)$ group. Improvement in histopathology features is indicated by decreased levels of epithelial cell damage in the tunica mucosa gastric. In the P1 group, the histopathology feature showed a reduced rate of tunica mucosa marked by the absence of epithelial cell erosion but still found infiltration of inflammatory cells. In the P2 group, the histopathology feature appears that the epithelial cells lining the mucous tunic are intact in some parts even though some are still ruptured. This improvement occurs because epithelial cells have undergone reepithelization but still found infiltrate inflammatory cells. In the P3 group, histopathology features suggest that the tissue has begun to look like a normal group of $\mathrm{K}(-)$, characterized by the mucosal tunica in the gastric tissue re-intact and no more epithelial debris due to erosion and inflammatory cell infiltration.
According to Hehi, et al., (2013), rupture of epithelial cells in the gastric can occur due to the irritation caused by several endogenous destructive factors, such as $\mathrm{HCl}$, pepsinogen, and bile secretion, as well as exogenous factors such as drugs, alcohols, bacteria and other chemical compounds, such as insecticides. Repair of epithelial cells in control group P1, P2, and P3 was caused by treatment of red pitaya peel extract with different dose in each treatment group, $150 \mathrm{mg} / 150 \mathrm{~g} \mathrm{BB}, 200 \mathrm{mg} / 150$ g BB, and $250 \mathrm{mg} / 150 \mathrm{~g} \mathrm{BB}$. Red pitaya peel extract contains a lot of antioxidants that are useful in warding off free radicals in the body is anthocyanin.

According to Sugiyanta, et al., (2013), anthocyanin activity in reducing epithelial damage in the gastric mucosa by donating hydrogen atoms and binding to metal ion transfer, inhibits oxidant enzymes or free radical production by cells and can regenerate gastric mucosa. According to Lianiwati (2011), anthocyanins work by donating hydrogen atoms to free radicals and causing them to become stable. The balance between oxidants and antioxidants causes the level of oxidative stress to be reduced. Decreased oxidative stress will reduce cell damage to the tissue, so that there will be improvements in the tissue organ.

\section{CONCLUSION}

This study concluded that the provision of red pitaya peel extract at a dose of $150 \mathrm{mg} / 150$ g BW was able to significantly decrease MDA levels and improve the histopathology feature of the gastric in white rats induced by diazinon.

\section{ACKNOWLEDGMENT}

The work report in this research was carried out in Bioscience Laboratory, Pharmacology Laboratory of UB's Medical Faculty, and UPT Materia Medika Batu, Malang. Thank you also to the all staff of UB's for assistance for the completion of this research. 
Indonesian Journal of Cancer Chemoprevention, June 2019 ISSN: 2088-0197

e-ISSN: $2355-8989$

\section{REFERENCES}

Budiyono, 2012, Kajian Sistematis Dampak Pestisida Diazinone Terhadap Manusia, Mamalia Lainnya Dan Lingkungan, Fakultas Kesehatan Masyarakat Universitas Indonesia.

Hehi, F.K., Durry, M.F. and Loho, L., 2013, Gambaran Histopatologi Tikus Wistar Pasca Pemberian Metanol, Jurnal e-Biomedik, 1(2), 890-895.

Lesmana, G.L., Diana, A., and Asus, M., 2013, Pengamatan Jaringan Lambung Kijing Taiwan (Anodonta Woodiana Lea) yang Terdedah Pestisida Diazinon 60 EC pada Beberapa Konsentrasi. Journal of Experimental Life Science, 3(2). Lianiwati, B.V., 2011, Pemberian Ekstrak Buah Naga Merah (Hylocereus polyrhizus) Menurunkan kadar F2 Isoprostan pada Tikus Putih Jantan (Albino rat) yang Diberi Aktivitas Berlebih. Tesis. Denpasar: Program Studi Ilmu Biomedik Program Pascasarjana Universitas Udayana.

Mishra, B.K.P. and Kumari, R., 2015, Effect of Pesticide on Hystology of Gastric and Liver of a Water Breathing Teleost, Mystus Tengara, Research Journal of Chemical and Enviroment Science, 3(5), 32-36.

Palupi, N.H., Aulanni'am, and Dyah, K.W., 2012, Studi Terapi Air Perasan Buah Labu Siam (Sechium endule) pada Tikus (Rattus norvegicus) Model Inflammatory Bowel Disease Pasca Induksi Indometasin Terhadap Kadar Malondialdehida dan Gambaran Histopatologi Duodenum, Fakultas Kedokteran Hewan, Universitas Brawijaya.
Putri, N.K.M., I Wayan, G.G. and I Wayan, S., 2015. Aktivitas Antioksidan Dalam Ekstrak Etanol Kulit Buah Naga Super Merah (Hylocereus costaricensis) dan Analisis Kadar Totalnya, Jurnal Kimia, 9(2), 243-251. Romdhoni, M.F. 2015, Pengaruh Pemberian Formalin Per-oral Terhadap Mukosa Lambung Tikus Putih Strain Wistar (Rattus norvegicus), Fakultas Kedokteran, Universitas Muhammadiah Purwokerto.

Sugiyanta, Dewi, O.S. and Azham, P., 2013, Pengaruh Pemberian Madu Terhadap Gambaran Histopatologi Lambung Tikus Wistar (Rattus norvegicus) Jantan yang Diinduksi Metanol, Fakultas Kedokteran, Universitas Jember. Wulandari, T., 2006, Pengaruh Pemberian Ekstrak Daun Sambiloto (Andrographis paniculata Ness.) Terhadap Struktur Mikroanatomi Hepar dan Kadar Glutamat Piruvat Transaminase yang Terpapar Diazinon, Fakultas Ilmu Matematika dan IImu Pengetahuan Alam, Universitas Sebelas Maret. Yulihastuti, D.A., Wayan, N.S., Iriana, S. and Made, N.S., 2016, Pengaruh Fungsi Hati Tikus Betina (Rattus norvegicus) yang Diinjeksi White Vitamin C dosis Tinggi Dalam Jangka Waktu lama Ditinjau dari Kadar SGPT, SGOT, Serta Gambaran Histologi Hati, Jurnal Metamorfosa, 3(1), 44-51.

Zulmi, N., 2016, Hubungan Antara Frekuensi dan Lama Penyemprotan dan Interval Kontras Pestisida Dengan Aktivitas Cholinesterase Petani di Desa Kembangkuning Kecamatan Cepogo, Fakultas IImu Kesehatan, Universitas Surakarta. 